\title{
Prevalence of Mobile Phone Dependence (MPD) among Medical Students: An Observational study
}

\author{
Nirmay Sonar ${ }^{1^{*}}$, Pradeep R Jadhav ${ }^{2}$, Mayuresh S. Jadhav ${ }^{3}$ \\ ${ }^{1 *}$ MGM Medical College, MGMIHS, Navi Mumbai, India. \\ 2,3 Department of Pharmacology, MGM Medical College, MGMIHS, Navi Mumbai, India.
}

\section{Keywords:} Addiction, Mobile phone, Dependence, Medical students

\begin{abstract}
Background \& Aim: With the advent of the smartphone, new unbounded possibilities have opened up, bringing with them an array of mental, behavioural, psychological and dependence issues. The study aimed to evaluate the prevalence of mobile phone dependence (MPD) among undergraduate medical students.

Methods: A cross-sectional, observational study was conducted. Three hundred and forty medical students, from each of the 4 years from a Medical College in Navi Mumbai were included. They were administered an MPD questionnaire and based on their responses, participants fulfilling three or more of the diagnostic criteria were rated as having MPD.

Results: Out of the total, mobile phone dependence was found in $15 \%(51 / 340)$ of undergraduate medical students. Higher prevalence of MPD was observed in males in comparison to females. MPD was significantly associated with the year of medical course, but not associated with gender, mobile phone type (smartphone users) and years of mobile phone usage.

Conclusion: Although the prevalence of mobile phone dependence (MPD) was low $(15 \%)$, it is only the tip of the iceberg. There is need to identify medical students with dependence syndrome for mobile phone so that early counselling, educational initiatives (for a self-corrective behavioural strategies) and treatment intervention can be planned and initiated.
\end{abstract}

\section{Introduction}

The World Health Organization (WHO), in accordance with ICD-10 (International Classification of Diseases, 10th Revision) defines dependence syndrome as being a cluster of physiological, behavioural, and cognitive phenomena in which the use of a substance or a class of substances takes on a much higher priority for a given individual than other behaviours that once had greater value [1].

The issue here is that dependence is only directed toward chemical substances or drugs. The entities of mobile phone and internet fall under non substance dependence. Mobile phones have become an essential part and parcel of modern life. In recent times, this gadget has become a necessity because of the countless perks it offers.

In Medical Students, who are predominantly young adults, this problem has a higher significance as these students will graduate, and effectively contribute to the Health Care system of a country. A high prevalence of stress among medical students is a cause of concern as it may impair behaviour of students, diminish learning, and ultimately affect patient care after their graduation.

The main sources of stress stated by the students were coping with their studies (60.3\%), followed by home environment $(2.8 \%)$. However, $36.9 \%$ of the students did not mention any source of stress.

The prevalence of stress of all levels was about $63.8 \%$, and the prevalence of severe stress was $25.2 \%$, according to a study [2]. As of January 2018, about 2.53 billion people worldwide carry a smartphone [3]. With the market changing every day, this number is bound to increase. With time, new problems with mobile phone usage have developed, such as Insomnia and Sleep apnea [4] ; lack of concentration and attention. Mental and behavioural problems aside, new entities such as Text Neck Syndrome [5], and Cell Phone Vision Syndrome [6] have come up. 


\section{Indian Journal of Medical Research and Pharmaceutical Sciences}

May 2021; 8(5)

ISSN: ISSN: 2349-5340

DOI: https://doi.org/10.29121/ijmrps.v8.i5.2021.2

Recently, the WHO brought up the concept of Gaming Disorder [7], predominantly affecting children and young adults.

Previous studies have shown the usage pattern of medical students in Kerala, India [8], as well as involvement of cell phones [9]. A study in Indore Medical College focused on the concept of Nomophobia, the fear of not having a mobile phone [10].

Similar studies in engineering students, and resident doctors showed that about $23.4 \%$ of residents were addicted to their smartphones. [11] International studies found widespread smartphone addiction among medical college students, which suggests that smartphone addiction has become a public health issue [12]. Therefore, this study was conducted to evaluate the prevalence of mobile dependence syndrome (MPD) among undergraduate medical students.

\section{Materials and methods}

Permission from the Institutional Ethical Committee (IEC) was obtained (approval number-2018/4/24).

Study design: Cross-sectional, questionnaire-based, observational survey

Site of study: Medical College, Navi Mumbai

Study participants: Undergraduate medical students

Study duration: 6 months

Sample size: 340 [Based upon prevalence of 33\%, 95\% confidence interval with $5 \%$ margin of error $=335$ ].

\section{Inclusion Criteria:}

1 Age: $18-25$ years

2 Any gender

3 Undergraduate medical students with personal mobile phone

4 Willing to participate or give informed consent

\section{Exclusion criteria:}

1 Undergraduate non-medical or paramedical student

2 Participants not having a personal mobile phone

3 Participants not willing to participate or give informed consent

4 Participants with known history of psychiatry disorders

\section{Materials}

1. Case record Form: To record the general information of the participants and information regarding the mobile phone use.

2. Mobile phone dependence (MPD) questionnaire: 20 items questionnaire with binomial response designed and validated by authors Aggrarwal, et al (11) to provide information about pattern of mobile use and whether such use fulfilled the ICD-10 criteria for dependence syndrome.

3. Informed consent documents - An informed consent form with participant information for voluntary informed consent for participation.

Procedure; Permission from the Institutional Ethics Committee was obtained. The procedures followed were in accordance with the ethical standards of the committee on human experimentation and with the Declaration of Helsinki, adopted by the 18th World Medical Assembly, revised in October 2008. After obtaining ethical committee and dean permission, the students were contacted personally by the researcher during the break / recess. The purpose of study and instructions for filling the MPD questionnaire will be explained and informed consent was obtained. Eligible students were asked to fill the MPD questionnaire and then the duly filled questionnaire was retrieved. Students failing to return the questionnaire, not willing to participate later at the time of giving questionnaire and incomplete filled forms were excluded from data analysis. Based upon the responses from questionnaire further evaluation was carried out to find whether such usage fulfilled the ICD-10 criteria for dependence syndrome. The diagnostic criterion with the questions used in the questionnaire included: Intense Desire (Q1), Impaired Control (Q3, Q8, Q11, Q19), Withdrawal (Q10, Q13, Q16), Tolerance (Q2), Decreased alternate pleasure(Q5, Q6, Q7, Q17) and Harmful Use (Q12). Participants who fulfilled three or more of the ICD-10 diagnostic criteria for substance 


\section{Indian Journal of Medical Research and Pharmaceutical Sciences}

May 2021; 8(5)

ISSN: ISSN: 2349-5340

DOI: https://doi.org/10.29121/ijmrps.v8.i5.2021.2

Impact Factor: 4.054

dependence were rated as having mobile phone dependence syndrome dependence syndrome for mobile phone usage as per ICD-10.

Statistical Analysis- Data was entered in Microsoft Excel and will be statistically analyzed using SPSS version 21. Data was expressed in terms of actual number, mean \pm standard deviation, frequency and percentage. Pearson's ChiSquare test/ Fisher's Exact was used for categorical data for establishing the association between variables

\section{Results}

A total of 340 undergraduate medical students were analyzed. The mean age of the participants was $20.2 \pm 1.5$ years. Out of the total, $161(47.4 \%)$ were males and $179(52.6 \%)$ were females. Majority had smart mobile phones with having usage for more than 5 years.

The positive responses to mobile phone dependence questionnaire are summarized in Table 1 . In this study, $63.8 \%$ participants responded that the mobile phone helps them to overcome bad moods, while $61.45 \%$ called back to most of the missed calls and $60.9 \%$ felt that they were getting addicted to mobile phone usage.

Table 1. Mobile phone dependence questionnaire responses

\begin{tabular}{|c|c|c|c|}
\hline \multirow{2}{*}{$\begin{array}{l}\text { Sr. } \\
\text { No. }\end{array}$} & \multirow[t]{2}{*}{ Questions } & \multicolumn{2}{|c|}{ Positive response (Yes) } \\
\hline & & Number & Percentage \\
\hline Q1 & $\begin{array}{l}\text { When not using the mobile, are you preoccupied with the mobile phone (Keep } \\
\text { constantly thinking about the previous and the future uses)? }\end{array}$ & 120 & 35.3 \\
\hline Q2 & $\begin{array}{l}\text { Do you need to use mobile phone for increased amounts of time in order to } \\
\text { achieve satisfaction/ betterment? }\end{array}$ & 116 & 34.1 \\
\hline Q3 & $\begin{array}{l}\text { Have you made unsuccessful efforts to control/ decrease or stop mobile phone } \\
\text { use? }\end{array}$ & 151 & 44.4 \\
\hline Q4 & Do you get upset when attempting to cut down mobile phone use? & 122 & 35.9 \\
\hline Q5 & Has mobile phone use led to decrease in meeting the friends in person & 156 & 45.9 \\
\hline Q6 & Has mobile phone use has made you spend less time with friends/ family & 171 & 50.3 \\
\hline Q7 & $\begin{array}{l}\text { Has mobile phone use has led to decrease in socialization? (meeting friends/ } \\
\text { hanging out ) }\end{array}$ & 161 & 47.4 \\
\hline Q8 & $\begin{array}{l}\text { Do you lose track of time after starting to use mobile phone for SMS, games, } \\
\text { music etc? }\end{array}$ & 207 & 60.9 \\
\hline Q9 & Do you lie to others to conceal the extent of your use of mobile phone? & 99 & 29.1 \\
\hline Q10 & $\begin{array}{l}\text { Do you become anxious of missing something if you have to switch off your } \\
\text { mobile phone for some reason? }\end{array}$ & 158 & 46.5 \\
\hline Q11 & $\begin{array}{l}\text { Do you compulsively respond to calls/ SMSs at places which don't permit } \\
\text { (Class, driving, group participation)? }\end{array}$ & 127 & 37.4 \\
\hline Q12 & $\begin{array}{l}\text { Do you compulsively respond to calls/ SMSs at places where it is dangerous to } \\
\text { do so (crossing road, driving/ working at machines)? }\end{array}$ & 83 & 24.4 \\
\hline Q13 & Do you call back to most of the missed calls? & 210 & 61.8 \\
\hline Q14 & $\begin{array}{l}\text { Does using mobile phone help you to overcome the bad moods (e.g. feeling of } \\
\text { inferiority, helplessness, guilt, anxiety, depression etc.)? }\end{array}$ & 217 & 63.8 \\
\hline Q15 & Do you feel guilty about the expenditure on (or excessive use of) mobile phone? & 180 & 52.9 \\
\hline Q16 & $\begin{array}{l}\text { Do you get irritated in the morning if you are not able to locate your mobile } \\
\text { phone? }\end{array}$ & 182 & 53.5 \\
\hline Q17 & $\begin{array}{l}\text { Do your families/ friends/ colleagues complain that your mobile phone use is } \\
\text { excessive? }\end{array}$ & 175 & 51.5 \\
\hline Q18 & $\begin{array}{l}\text { Do you get annoyed or shout if someone asks you to decrease the use of mobile } \\
\text { phone? }\end{array}$ & 127 & 37.4 \\
\hline Q19 & Do you frequently participate in SMSs or phone entry competitions? & 52 & 15.3 \\
\hline Q20 & Do you think you are getting addicted to mobile use? & 207 & 60.9 \\
\hline
\end{tabular}




\section{Indian Journal of Medical Research and Pharmaceutical Sciences}

May 2021; 8(5)

ISSN: ISSN: 2349-5340

DOI: https://doi.org/10.29121/ijmrps.v8.i5.2021.2

Impact Factor: 4.054

The prevalence of Mobile Phone Dependence was found to be $15 \%$ among undergraduate medical students. The most commonly met ICD-10 diagnostic criteria for dependence syndrome were intense desire (35.6\%) followed by (34.4\%) impaired control (Table 2).

Table 2. Criterions for Mobile Phone Dependence

\begin{tabular}{|l|l|l|l|}
\hline $\begin{array}{l}\text { Sr. } \\
\text { No. }\end{array}$ & ICD-10 Criteria for Dependence syndrome & $\begin{array}{l}\text { Number } \\
(\mathrm{N}=340)\end{array}$ & Percentage \\
\hline 1 & Intense Desire (Q1) & 121 & 35.6 \\
\hline 2 & Impaired control (Q3,8,11,19) & 117 & 34.4 \\
\hline 3 & Withdrawal (Q10,13,16) & 4 & 1.2 \\
\hline 4 & Tolerance (Q2) & 53 & 15.6 \\
\hline 5 & Decreased pleasure (Q5,6,7,17) & 47 & 13.8 \\
\hline 6 & Harmful use (Q12) & 83 & 24.1 \\
\hline 7 & $\begin{array}{l}\text { Mobile Phone Dependence } \\
\text { (i.e. Participants fulfilling three or more of the above six criteria) }\end{array}$ & $\mathbf{5 1}$ & $\mathbf{1 5}$ \\
\hline
\end{tabular}

On subgroup analysis, mobile phone dependence was significantly associated with year of medical course $(\mathrm{p}=0.019)$, but not associated $(\mathrm{p}<0.05)$ with gender, mobile phone type (smartphone users) and years of mobile phone usage (Table 3 ).

Table 3. Association between Mobile Phone Dependence and various parameters

\begin{tabular}{|c|c|c|c|c|c|}
\hline \multicolumn{2}{|l|}{ Parameter } & \multirow{2}{*}{$\begin{array}{l}\text { MPD Present } \\
(\mathrm{N}=51) \\
28\end{array}$} & \multirow{2}{*}{$\begin{array}{l}\text { MPD Absent } \\
(\mathrm{N}=289) \\
133\end{array}$} & \multirow{3}{*}{$\begin{array}{c}\text { Chi square } \\
\text { value } \\
1.37\end{array}$} & \multirow{3}{*}{$\begin{array}{r}\text { P value } \\
0.242\end{array}$} \\
\hline \multirow[t]{2}{*}{ Gender } & Male & & & & \\
\hline & Female & 23 & 156 & & \\
\hline \multirow[t]{4}{*}{ Year of Medical course } & $1 \mathrm{st}$ & 7 & 26 & \multirow{4}{*}{9.9} & \multirow{4}{*}{0.019} \\
\hline & $2^{\text {nd }}$ & 18 & 129 & & \\
\hline & $3 \mathrm{rd}$ & 18 & 54 & & \\
\hline & 4th & 8 & 80 & & \\
\hline \multirow[t]{2}{*}{ Type of phone } & Smart & 50 & 285 & \multirow{2}{*}{0.1} & \multirow{2}{*}{0.75} \\
\hline & Non-smart & 1 & 4 & & \\
\hline \multirow{2}{*}{$\begin{array}{l}\text { Years of mobile phone } \\
\text { usage }\end{array}$} & $<5$ & 26 & 125 & \multirow{2}{*}{1.04} & \multirow{2}{*}{0.30} \\
\hline & $\geq 5$ & 25 & 164 & & \\
\hline
\end{tabular}

\section{Discussion}

The findings of the present suggest that the prevalence of Mobile Phone Dependence in undergraduate medical students was $15 \%$ as per ICD-10 diagnostic criteria based questionnaire for dependence syndrome.

Studies had reported the presence of a high burden of mobile phone addiction-like behavior and nomophobia among school children and Indian youth creating a public health concern [6,13]. As time and technology keep taking leaps and bounds in a never stopping race, we feel that dependence on mobile phones will have a paramount importance and impact in medical professionals also

In the present study, $15 \%$ met the ICD-10 diagnostic criteria for Mobile Phone Dependence, with intense desire followed by impaired control as commonly involved criterions. Around 63\% participants responded that the mobile phone helps them to overcome bad moods, while $61 \%$ called back to most of the missed calls and $60 \%$ felt that they were getting addicted to mobile phone usage. Feeling of guilt, losing track of time and irritability on not able to locate mobile phone was also commonly encountered in this study. 


\section{Indian Journal of Medical Research and Pharmaceutical Sciences}

May 2021; 8(5)

ISSN: ISSN: 2349-5340

DOI: https://doi.org/10.29121/ijmrps.v8.i5.2021.2

Impact Factor: 4.054

Several studies across India have estimated the prevalence of dependence syndrome ranges between $18.5 \%-52 \%$ in medical students and residents $[8,9,10,11,12,14,15]$. This variation is due to methodological heterogeneity arising from the different questionnaires used for assessment of mobile phone dependence. George et al, observed in medical students that false perception of ring (ringxiety)and waking up from sleep to check the mobile for call or message was an indicator of mobile phone addiction/dependence [8]. Similarly, Arumugam et al, documented that in majority of medical students have experienced health problems like headache, sleep disturbance, ear pain, irritability and were addicted to mobile phones [14].

In present study, dependence syndrome for mobile phone usage was significantly associated with the year of medical course. Similarly, Dixit et al have documented that maximum medical students of $3^{\text {rd }}$ year part -1 were having high dependence (nomophobia score $>24$ ) score [10]. The present research, however, did not find any association between mobile phone dependence with gender., smart phone and years of usage.

The strength of this article is that it addresses the issues of mobile phone dependence syndrome in undergraduate medical students which needs to be recognized for implementing preventive health intervention strategies. Our study had some limitations. It was a cross-sectional study; dependence assessment was based on self-rated questionnaire. The study was conducted at a single institute and hence the findings cannot be extrapolated to general population.

\section{Conclusion}

In conclusion, the prevalence of mobile phone dependence syndrome in undergraduate medical students was found to be $15 \%$. This number, however, is only the tip of the iceberg. There is need to identify medical students with dependence syndrome for mobile phone so that early counseling, educational initiatives for a self-corrective behavioral strategies and treatment interventions can be planned and initiated.

\section{Acknowledgements}

Our sincere gratitude extends to all the medical students, who have participated in this study.

\section{References}

1. World Health Organization (WHO). Dependence Syndrome by WHO. Available at http://www.who.int/substance_abuse/terminology/definition1/en/

2. Abdulghani HM, AlKanhal AA, Mahmoud ES, Ponnamperuma GG, Alfaris EA. Stress and its effects on medical students: a cross-sectional study at a college of medicine in Saudi Arabia. J Health Popul Nutr. 2011 Oct;29(5):516-22.

3. Statista. Number of smartphone users worldwide from 2014 to 2020 (in billions) by Statista 2018Available at https://www.statista.com/statistics/330695/number-of-smartphone-users-worldwide/

4. Khan MN, Nock R, Gooneratne NS. Mobile Devices and Insomnia: Understanding Risks and Benefits. Curr Sleep Med Rep. 2015 Dec;1(4):226-231.

5. Neupane S, Ifthikar A, Mathew A. Text Neck Syndrome - Systematic Review. Imperial Journal of Interdisciplinary Research. 2017;3(7):142-47.

6. Sadagopan AP, Manivel R, Marimuthu A, Nagaraj H, Ratnam K, et al. (2017) Prevalence of Smart Phone Users at Risk for Developing Cell Phone Vision Syndrome among College Students. J Psychol Psychother 7:299.

7. World Health Organization (WHO). Gaming disorder. Available at http://www.who.int/features/qa/gaming-disorder/en/

8. George S, Saif N, Joseph BB. A study on the mobile phone usage pattern and its dependence among medical students of a college in Kerala, India. Int J Res Med Sci 2017;5:3615-9.

9. Rupani MP, Parikh KD, Trivedi AV, Singh MP, Patel A, Vadodariya B, Bhagora B, Sharma B. Crosssectional study on mobile phone involvement among medical students of a tertiary care teaching hospital of western India. Natl J Community Med 2016; 7(6):609- 613. 


\section{Indian Journal of Medical Research and Pharmaceutical Sciences}

May 2021; 8(5)

ISSN: ISSN: 2349-5340

DOI: https://doi.org/10.29121/ijmrps.v8.i5.2021.2

Impact Factor: 4.054

10. Dixit S, Shukla H, Bhagwat AK, et al. A study to evaluate mobile phone dependence among students of a medical college and associated hospital of Central India. Indian J Community Med. Apr 2010;35(2): 339 341.

11. Aggarwal M, Grover S, Basu D. Mobile Phone Use by Resident Doctors:Tendency to Addiction-Like Behaviour. German J Psychiatry 2012;15(2): 50-55.

12. Chen B1, Liu F, Ding S, Ying X, Wang L, Wen Y. Gender differences in factors associated with smartphone addiction: a cross-sectional study among medical college students. BMC Psychiatry. 2017 Oct 10;17(1):341.

13. Nikhita CS, Jadhav PR, Ajinkya S. Prevalence of mobile phone dependence in secondary school adolescents. J Clin Diagn Res. 2015;9:VC06-9.

14. Arumugam B, Sachi S, Nagalingam S. A descriptive study on behavior associated with mobile phone usage and its effect on health among medical students in Chennai. Journal of Evolution of Medical and Dental Sciences. 2014;3(7):1590-5.

15. Basu S, Garg S, Singh MM, Kohli C. Addiction-like Behavior Associated with Mobile Phone Usage among Medical Students in Delhi. Indian J Psychol Med. 2018;40(5):446-451.

\section{Author Bibliography}

\begin{tabular}{|l|l|}
\hline Dr. Nirmay Sonar \\
$\begin{array}{l}\text { Dr. Nirmay has completed his graduation with honors from MGM } \\
\text { Medical College, and now is pursuing higher studies, trying to break } \\
\text { social barriers in the field of medicine. } \\
\text { Email: nirmay9833@gmail.com }\end{array}$ \\
\hline $\begin{array}{l}\text { Dr. Pradeep R Jadhav } \\
\text { Department of Pharmacology, MGM Medical College, Navi-Mumbai, } \\
\text { India }\end{array}$ \\
\hline $\begin{array}{l}\text { Mr. Mayuresh S. Jadhav } \\
\text { Currently pursing M.Sc (Medical Pharmacology) } \\
\text { Department of Pharmacology, MGM Medical College, Navi- } \\
\text { Mumbai, India }\end{array}$ \\
\hline
\end{tabular}

